\title{
Festivals, cultural intertextuality, and the Gospel of John's rhetoric of distance
}

\begin{abstract}
Author:
Warren Carter ${ }^{1,2}$

Affiliations:

${ }^{1}$ New Testament, Brite

Divinity School, Texas

Christian University, United

States

${ }^{2}$ Department of New

Testament, University of

Pretoria, South Africa

Note:

Prof. Dr Warren Carter is a member of the editorial

board of HTS Teologiese

Studies/Theological

Studies; this article is

dedicated to Prof. Dr

Andries G. van Aarde

with appreciation for his

generous spirit, energetic

leadership and insightful

and creative scholarship.

Prof. Dr Warren Carter

is also participating as

research associate of Prof.

Dr Andries G. van Aarde,

Honorary Professor in

the Department of New

Testament Studies, Faculty

of Theology, University of
\end{abstract}

Pretoria, South Africa.

\section{Correspondence to:}

Warren Carter

email:

warren.carter@tcu.edu

\section{Postal address:}

Brite Divinity School, Texas

Christian University, TCU

Box 298130, Fort Worth TX

76129, United States

Dates:

Received: 17 Feb. 2010

Accepted: 07 Apr. 2010

Published: 07 June 2011

How to cite this article Carter, W., 2011, 'Festivals, cultural intertextuality and the Gospel of John's rhetoric of distance', HTS Teologiese Studies/ Theological Studies 67(1), Art. \#802, 7 pages. DOI: 10.4102/hts.v67i1.802

(C) 2011. The Authors. Licensee: OpenJournals Publishing. This work is licensed under the Creative Commons Attribution License.
Imperial and civic-religious festivals pervaded the late first-century city of Ephesus where John's Gospel was, if not written, at least read or heard. How did Jesus-believers as likely members of somewhat participationist synagogue communities negotiate such pervasive and public celebration of festivals? Did they participate in, ignore, or oppose such festivals? And how might John's Gospel have encouraged them to respond?

This article engages these questions by focusing on the narrative presentation of festivals in John's Gospel (some 42 times) as, amongst other things, occasions of conflict and condemnation. Employing Sjef van Tilborg's notion of 'interference', which prioritises the Ephesian civic interface of the Gospel's audience, the article argues that the cultural intertextuality between the Gospel and an Ephesian context destabilises and problematises Ephesian civic festivals and shows there to be fundamental incompatibilities between Jesus' work and Ephesian society, thereby seeking Jesus-believers to absent themselves from festivals. The Gospel's presentation of festivals belongs to the gospel's rhetoric of distance vis-à-vis societal structures.

\section{Introduction}

According to a 568-line inscription displayed at the entrance to the Ephesian theatre and in the Artemision (IE 1a 27; Wankel 1979-1984), ${ }^{1}$ a wealthy, landowning Roman of the equestrian order, C. Vibius Salutaris, made a large donation to Ephesus in 103-104 CE (Rogers 1991:153-185). Amongst several provisions, Salutaris established a procession through Ephesus every two weeks. Taking about 90 minutes, it followed a circular and carefully choreographed route that embraced Roman, Hellenistic and mythological dimensions of the city's sacred identity rooted in Artemis. The procession bore some 31 images, 9 representing Artemis, others representing various Roman personnel (Augustus, the Roman emperor and his wife, the Roman senate, the Roman people), and 15 representing central figures and aspects of Ephesian life including Androklos, responsible for the city's founding, and Lysimachos, a Hellenistic king who re-founded the city in the 280s BCE.

What did Jesus-believers in Ephesus do during this bi-weekly celebration? Its route through significant areas of the city, its festival nature with 31 images, and its bi-weekly frequency suggest it was not easily avoided. Did Jesus-believers in Ephesus - amongst whom John's Gospel was, if not written, probably read and heard ${ }^{2}$ - avert their eyes, turn their backs, utter the name of Jesus, or find another route? Or did the procession not trouble them so that they continued on with their daily business? Or did they join it as active participants and/or as spectators? We of course cannot know for certain; historical imagination is inevitably at work in the argument that follows, just as it is in all historical reconstruction.

Such questions have received little attention in relation to John's Gospel; this discussion can be an initial exploration only. The neglect of the interface between the Gospel narrative and an Ephesian cultural context is no surprise given the restricted interests of much Johannine scholarship more concerned with a supposed separation from a synagogue or with reading strategies that spiritualise and individualise the Gospel. A solitary focus on a synagogue and a reading strategy that views John as an exclusively religious text artificially and anachronistically isolate it from social, cultural, and Imperial realities.

Yet positing that John-reading, Jesus-believers in Ephesus were isolated from their daily world and society is impossible to sustain. The recognition of their societal involvement might

1.I list Ephesian inscriptions hereafter by volume and number (I.19).

2.Irenaeus (Adv Haer 3.1.1) links John's writing with Ephesus; see also Eusebius, Hist. eccl. 3.23.6-19. To be clear, I am not arguing that John's Gospel originated in Ephesus or intended to address believers in the city explicitly, but I am making the reasonable assumption that it was read or heard in the city. This paper explores just one aspect of the possible interaction between the Gospel and this multidimensional urban context. 
proceed by various means if space permitted, including the Gospel's participationist presentation of Jesus (17:15; 18:20). Another approach - which I can only outline here, but which I sustain in my John and Empire (Carter 2008) might begin with recognising that the long-held focus on the separation of Jesus-believers from a synagogue (the BrownMartyn scenario) increasingly fails to be persuasive (Carter 2008:22-26). The consequence of this acknowledgement is the recognition that Jesus-believers were probably part of a synagogue community. As recent work has shown (Trebilco 1991; Barclay 1996; Gruen 2002; Harland 2003), synagogues were not culturally isolated communities, but commonly maintained considerably, though not completely porous boundaries which allowed multiple and simultaneous societal interactions. John's Gospel disapprovingly styles Jesus-believers who were part of synagogue communities not as opponents of high Christology, as Raymond Brown argues (1979:71-73), but as fearful and committed to the love of human glory'(12:42-43) - the love of honour and status so fundamental to Hellenistic and Roman societies gained and secured through societal participation (Barton 2001; Keener 2003:886-888).

In order to begin to pursue the question of how John-reading or hearing, Jesus-believers might have negotiated civic participation in Ephesus, I assert (without arguing) three claims concerning John's Gospel and its audience:

- Firstly, I posit that, wherever it was written, John was at least read and heard in Ephesus (Irenaeus Adv Haer 3.1.1; also Eusebius Hist. eccl. 3.23.6-19). My focus is its possible reception in and interaction with such a context.

- Secondly, to pursue the intertextualities between John's Gospel and an Ephesian context beyond the synagogue, I adopt an approach pioneered by Sjef van Tilborg (1996) in his exploration of the 'interference' between John's Gospel and the large corpus of Ephesian inscriptions. In Reading John in Ephesus, Van Tilborg prioritises Ephesian referents over Galilean or Jerusalem referents. In this way, he argues, for an Ephesian, Jesus-believing audience, the Gospel presentation of chief priests has interference not with Jerusalem structures or personnel, but with elite chief priests in Ephesus. Similarly, for an Ephesian audience, the Gospel's presentation of the Jerusalem temple has interference not with the Jerusalem temple but with temples - Artemis, Imperial, numerous deities - experienced daily in Ephesus. On the same basis, I explore the interference for an Ephesian audience between the festivals presented in the Gospel's narrative, on the one hand, and the Ephesian context, on the other, in which civic festivals were pervasive.

- Thirdly, Jesus-believers in Asia were conflicted over cultural and cultic participation. This struggle is attested, for example, in Revelation 2-3 in the struggle between John and 'Jezebel' and their supporters (Carter 2009), in the command to honour the emperor in 1 Peter 2:17 (cf. 1 Cor 8-10) (Carter 2004) and, as will become evident, in the interaction between John's Gospel and Jesus-believers in Ephesus.

\section{Pervasive Ephesian festivals}

Salutaris' procession was of course not the only such festival in Ephesus. Pervading the civic landscape were Imperial cult celebrations and observances of various 'cults and deities' including those of Aphrodite, Apollo, Artemis, Asclepius, Athena, Demeter, Dionysus, Isis and Sarapis, the Mother goddess, Hestia, Zeus, Hero cults, and other deities (Oster 1990; Mitchell 1990). Public processions, sacrifices, games and feasts manifested divine presence and purposes, defined public time and space, embraced elites and non-elites and constituted the city's sacred identity as blessed by, and beholden to, the gods manifested in their midst.

Major festivals shaped the urban calendar and conception of time (Price 1984:106). In the month of Lenaeon, the annual Dionysia (celebrating vine-growing and its produce) involved feasting and drinking (I.9), and probably theatrical performances (Strabo 14.1.29). The annual Artemisia occurred in the month of Artemision (March-April). On the 6th of Thargelion (May-June), a procession in Ephesus celebrated Artemis' birth (Ia.27 lines 224-225) as one of numerous Artemis feasts (IV.1078) and festivals (III.987, 988; Oster 1990:1673, 1709-1711). The prytanis - the very wealthy, annually-elected, influential president of the city council - led an annual procession bearing an adorned image of Artemis to Hestia in the prytaneum in the city centre for a ritual involving sacrifice, prayers, music, and incense (Van Tilborg 1996:159).

Along with this Ephesian calendar, Price (1984:54-55, 106) notes that the province adopted a new calendar beginning the new year on Augustus' birthday. Regular festivals for Imperial birthdays (VII.2.3801.2), 'sacrifices to the Sebastan gods and ... festivals and feasts' (VII.1.3420; VII.2.3801), games (II.261; III.859A; VII.2.3801.2, 3825), gladiatorial contests and banquets (VI.2037, 2061-2063) were held (Van Tilborg 1996:176-179, 190-191). Imperial celebrations were combined with local festivities such as that of Asclepius (III.719) and Demeter (agriculture and harvest) in which the Roman proconsul customarily participated and funded sacrifices (II.213). The Demeter cult-association established a priesthood to venerate Livia, Augustus' wife (VII.2.4337).

In addition to temporal presence, festivals pervaded the city spatially as Salutaris' procession indicates. Van Tilborg (1996:68), noting the sacrificial activity of the Artemis temple (I.10; IV.1210A) and its embeddedness in the city's socioeconomic structures, argues intertextually that, 'the Artemis temple colours all the activities in the city in a way that can be compared to the function of the temple in Jerusalem' in John's Gospel. Xenophon's Ephesian Tale narrates a festive procession in Ephesus' streets, marked by what Simon Price (1984:102) calls a 'carnival atmosphere:'

It was the time when the local festival of Artemis was being celebrated and the procession was going from the city to the sanctuary, a distance of three kilometers. All the local girls had to process, richly adorned, and the young men ... A great crowd 
both of locals and foreigners gathered for the spectacle ... The members of the procession filed past, first the carriers of the sacred objects, torches, baskets and incense burners, then horses, dogs, and hunting equipment for war and especially for peace ...

(1.2.2-5; Price 1984:110)

Price (1984:174-75, 189) notes that sacrifices - to which garlanded animals were commonly escorted (Artemis V.1577A, B) - occurred in central areas. The council house included an Imperial altar as did the stadium where games were held (IV.1139). Imperial images, including cult statues, were located not only in the temple of Artemis but also in the theatre (I.28; VI.2047-48), near the harbour (II.508, 518), in the market (II.404), near fountains (II.413, 420) and in private houses (I.27 line 150-51; I.28; II.267; Van Tilborg 1996:192-196). In its temporal and spatial structure, 'the city ... radiates (Imperial) cult' (Van Tilborg 1996:196) as a locus of divine blessing and presence.

In addition to temporal and spatial reach, festivals had extensive social reach, involving man and woman, elites and non-elites. Elite men and women (Wood 1999; Kraemer 1992:80-92) commonly provided funding (Price 1984:62-65, 101-32) for festivals, feasts and spectacles (e.g. gladiatorial displays, horseracing, animal fights, athletic contests), priesthoods (Friesen 1993:76-113, 169-214), ${ }^{3}$ cult statues, decorations, incense, and sacrifices. They also functioned as priests or priestesses and/or officials (Friesen 1995:244-45) and participated in festival processions.

The very wealthy and influential Tib. Kl. Aristion, for instance, responsible for various civic benefactions, became the first high priest of the temple of the Sebastoi in 88/89 (II.239, 240; V.1498). Typical of the prominent civic roles of elite women (MacMullen 1980:213-214; Kearsley 1986; Boatwright 1991; Trebilco 1991:58-60; Friesen 1993:81-89; Harland 2003:112, n. 48), his wife Julia Lydia Laterane is a high-priestess, though whether of the Imperial cult or of Artemis is not clear (II.424, 424A), the prytanis (presiding over the city council), and patroness of the Dionysus association (II.424, 424A; V.1601E; Van Tilborg 1996:157-158, 161). Two other husband and wife pairings are chief priests and priestesses of the Imperial cult, as is the very wealthy and powerful woman, Vedia Marcia (IV.1017; Van Tilborg 1996:101-106, 157). Five elite women function as high-priestesses of Artemis and 18 as priestesses (Van Tilborg 1996:156-158). A woman, Servilia Secunda, was priestess of Demeter, associated with the veneration of Livia Augustus (VII.2.4337). Men and women (inscriptions identify nine women), occupied Ephesus' top 'civic' position, the prytanis, who presided over the city council and maintained the flame of the city hearth, ensuring Hestia's favour for the city (Van Tilborg 1996:158-61). In addition, he or she paid for 365 animal sacrifices for Artemis and participated in the daily ritual (I.10; IV.1210A).

Non-elites also participated in festivals, contests, processions, meals, and cultic ceremonies that pervaded the city's streets, buildings, and public spaces. Associations

3.Price (1984) comments that these priesthoods 'like priests of traditional cults, were not specialists' (p. 63); the duration could vary from single occasions (p. 103) to lifelong and hereditary offices (p. 63).
(Harland 1996:328-334, 2000:110-116; Kraybill 1996:110135; Kloppenborg and Wilson 1996), crucial for the socioeconomic activity of artisans and merchants (Broughton 1938: 841-846; Meijer \& Nijk 1992:42, 75-78, 201), provided non-elites (citizens and non-citizens, free and slave, males and females) with opportunities to honour sponsoring deities and the emperor (MacMullen 1980: 210-212; Barton 1981:9; Joshel 1992:141-145). Harland (1996:324) notes that of the 'about 100 inscriptions relating to associations and guilds in Ephesus (I-III CE) ... over 20 pertain ... either to worshipping or honouring the emperor ...' Associations of hymn-singers and other performers and athletes were active in festivals (Harland 1996:326-328; Millar 1977:456463). Other associations used networks of civic benefaction to dedicate statues, altars, or inscriptions to the emperor or related officials (Harland 2000:110-112, n. 48, n. 51). Associations also honoured patron gods and the emperor (and/or previous emperors, the Sebastoi or 'revered ones') in mysteries, prayers, sacrifices and meals that included food offered to the gods (Harland 1996:332-333, 2000:112-113; Pleket 1965).

By ordering civic space and time and facilitating social bonding, festivals participated in, and enacted, a cosmic order in Ephesus. They mediated the presence, will, and blessings of the city's protector Artemis and of other deities, as well as the social order of the divinely sanctioned Romans. Festivals were crucial to the city's sacred identity. How did John-reading, Jesus-believers negotiate such identities?

\section{John's Gospel: Constructing festivals as contexts of conflict and/or condem- nation}

Jesus regularly attends festivals throughout John's narrative. Interpreters have examined the Gospel's 42 references to festivals $^{4}$ in relation to significant Gospel themes such as the temple (Kerr 2002:205-267), Jesus' hour (Daise 2007), Christology (Yee 1989), and/or to a posited post-70 situation of conflict with and separation from a synagogue (Yee 1989:24-27).

My focus here, shaped by Van Tilborg's approach of Ephesian 'interference' (van Tilborg 1996), concerns the cultural intertextuality between the Gospel depictions of festivals and the numerous and various festivals of late first-century Ephesus. ${ }^{5}$ Much previous discussion has discussed the Johannine festivals at length, identifying the focus of festivals such as Passover, Tabernacles, Dedication and Sabbath and assessing the contribution of their traditions, rituals and symbols to the particular exchanges between Jesus and the Jerusalem authorities. These discussions have shown that Jesus uses festival motifs simultaneously to define himself and to (re-)define the festivals. I will not rehearse those rich

4.The generic term 'feast' or 'festival' [ēorte] appears seventeen times, 'Sabbath' [sabbaton] thirteen times, 'Passover' [pascha] ten times, 'tabernacles' ([skēnopegia] 7:2]) and 'festival of dedication' ([egkainiaa] 10:22]) once each.

$5 . I$ do not explore possible implications for the interaction between Jesus-believers and the rest of the synagogue community. 
discussions here for several reasons. Partly, space precludes it and partly it is precisely this restricted focus that I wish to move beyond in this article. Previous scholarship has almost invariably assessed the functions of the festivals only in synagogal contexts and in terms of contested traditions where struggles over the interpretation of the festal repertoire have been central to the Gospel narratives. My concern here is to move beyond intra-synagogal debates and offer an initial exploration of some of the possible interactions between the Gospel's festal narratives and the civic festivals familiar to Jesus-believing readers or hearers in Ephesus. Such readers may well be involved in intra-synagogal disputes over the significance of festivals; this article will set that dimension aside and focus only on some possible interactions with civic Ephesian festivals.

It can be noted that a dominant feature of the Gospel's presentation of festivals concerns the frequent presence of conflict and condemnation. I am not claiming that conflict and condemnation are the only dynamic that festivals denote, nor that conflict and condemnation occur only in the context of festivals. Rather, the Gospel frequently presents festivals as, among other things, contexts or spaces in which significant conflict occurs between Jesus and his opponents and in which Jesus frequently announces condemnation on his opponents. This more general level of presentation offers a good starting place for exploring their interface with Ephesian civic festivals.

The following brief survey indicates the presence of conflict and condemnation through the festival narratives. The narrative connection between festivals and conflict or condemnation emerges with the first reference to a festival at 2:13 (cf. 4:45, where the word occurs twice). Passover provides the space or occasion in which Jesus conflicts with the Romeallied, Jerusalem temple establishment, denouncing its preference for trade (2:16). The Ioudaioi ${ }^{6}$ or temple leaders demand a sign or authorisation for Jesus' action, but do not comprehend his answer (2:19-20). The reference to Jesus' zeal for God's house consuming him (2:17) and Jesus' selfreferencing words (2:19, 'destroy this temple') denote the conflict's fatal intensity.

Three factors indicate the presence of condemnation. Firstly, Jesus' echoing of the eschatological passage of Zechariah 14:21 in 2:16 ('and there shall no longer be a trader in the house of the Lord of hosts on that day') indicates God's judgment on 'business as usual' in the temple. Secondly, the link between the temple and Jesus' body (2:21) relocates the temple in the resurrected person of Jesus as the locus of divine encounter and revelation. And third, the Gospel originates after Titus' troops had destroyed the temple (Haenchen 1984:187), an act widely interpreted as God's condemnation of the temple and its leaders. $^{\text {? }}$

6.This term, preferable to the problematic 'the Jews,' denotes a subgroup comprising Jerusalem-temple-based leaders $(1: 19 \cdot 2 \cdot 2 \cdot 18,20 \cdot 3 \cdot 1)$ and supporters $(6: 41,52)$ Jerusalem-temple-based leaders $(1: 19 ; 2: 2: 18,20 ; 3: 1)$ and supporters $(6: 41,52)$,
chief priests and leading Pharisees $(18: 3,13 ; 19: 14-15)$ allied with Rome $(11: 45-53)$ and often conflicting with Jesus (Carter 2008:156-158, 173-174, n. 63).

7.4 Ezra 3:28-36; 5:21-30; 2 Bar 1:1-5; Josephus, Ant. 20.166; Matthew 22:7.
Passover in Jerusalem is also the occasion for conflict over interpreting Jesus' signs (2:23-25). The conflict becomes evident in 3:1-12 as Jesus scorns the non-discerning Nicodemus for lacking understanding (3:10), not believing (3:12), and condemning $(3: 16,18)$. The issue of (not) understanding Jesus' signs as revelations of divine blessing recurs throughout as a constant point of conflict and condemnation. ${ }^{8}$

The unnamed festival in 5:1 and the Sabbath $(5: 9,10,16$, 18) provide another occasion in Jerusalem (5:1) for conflict and condemnation. The conflict between Jesus and the Ioudaioi initially concerns Sabbath-healing (5:9-10, 16), but quickly develops to matters of discerning divine, life-giving purposes and Christological identity, authority and agency (5:18-47). This conflict intensifies as 'the Ioudaioi' seek to kill Jesus' (5:18a). Jesus' subsequent prosecutory discourse condemns them for not listening to God's voice (5:37), not believing Jesus $(5: 38,40)$, lacking the love of God $(5: 42)$, not receiving Jesus (5:43), not seeking God's glory (5:44) and not believing either Moses or Jesus (5:45-47). Moses also accuses them before God (5:45).

Conflict occurs at the Galilean Passover (6:4), though it seems less intense. After inquiring about Jesus' origin (6:25), the works of God (6:28), a sign (6:30) and bread from heaven (6:34), the Ioudaioi murmur because - ironically - they 'know' his father and mother (6:41-42) and contest eating his flesh (6:52). Not believing, they are condemned and do not participate in eternal life $(6: 47,53-54)$. Jesus also conflicts with some disciples, who likewise 'murmur,' which Jesus ominously equates with being scandalised or offended (6:61) and not believing (6:64).

Tabernacles $(7: 2)^{9}$ provide another opportunity for conflict and condemnation that intensify through chapters $7-8$. The Ioudaioi want to kill Jesus ( $\dot{\alpha} \pi \circ \kappa \tau \in \dot{i} \nu \omega 7: 1,19,20,25 ; 8: 37)$, the chief priests and Pharisees want to arrest him (7:32; cf. 7:30, $44 ; 8: 20)$ and the Ioudaioi take up stones against him (8:59). Jesus is accused of being demon-possessed $(7: 20 ; 8: 48,52)$, deceiving $(7: 12,47)$, bearing false testimony $(8: 13)$ and being a Samaritan (8:48). They misunderstand his origin and destiny $(7: 32-36,40-44 ; 8: 27)$, his identity (8:25), and thereby reveal their own origin, destiny, and lack of relationship with God (8:42-47). Among the people, there is muttering (7:12, 32 ) and division (7:43). Jesus accuses his opponents of hating him (7:7), not keeping the law and wanting to kill him (7:19). Condemning them, he declares their destiny is not with God (7:33-34; 8:21-22), they do not know his origin and destiny $(7: 14 b)$, nor Jesus or God $(8: 19,55)$, they are of the devil $(8: 23$, $41-44)$, they are slaves of $\sin (8: 34)$, they do not understand $\operatorname{him}(8: 43)$, they are not from God (8:47), they are liars (8:55). They fail to encounter the divine or recognise Jesus' lifegiving work and revelation, thereby condemning themselves to die for not believing in Jesus $(8: 24,45,47)$. They cannot hear (i.e. believe) because they are not from God (8:47).

8.John $5: 16-18 ; 6: 41 ; 7: 14-31 ; 9: 24,29,39 ; 10: 31-39 ; 11: 45-53$.

9.7:8 (occurring twice), 10, 11, 14, 37; Sabbath, 7:22, 23 (occurring twice). 
More conflict follows with the Sabbath healing in Jerusalem of the man-born-blind $(9: 14,16)$. Here, the conflict is not, initially, directly with Jesus, but with the healed man who, as has often been noted, gains more insight into Jesus' identity and revelation of God as pressure is exerted on him. ${ }^{10}$ After doubts about his story (9:18), parental denials (9:19-21), sharp exchanges (9:24-27a) and sarcasm (9:27b), the man is 'cast out' for attempting to teach the Jerusalem elite (9:34). While the healed man gains insight, the elite deny any revelation or encounter with the divine through Jesus. He is not from God (9:16), he is a sinner (9:24), God has not spoken to him and his origin is unknown (9:29). Jesus enters the scene to condemn them for declaring that they 'see' when they do not (9:39-41) and to denounce them as thieves and robbers or brigands $(10: 1,8,10)$.

The festival of Dedication contextualises more conflict in Jerusalem and the temple (10:22-23). The Ioudaioi ask if Jesus is the Christ. He answers that he had told them but they did not believe; only those who believe participate in eternal life and never perish (10:25-28). Their condemnation is clear, as is the conflict. The Ioudaioi attempt to stone him (10:31), accuse him of blasphemy (10:32-38), and seek his arrest (10:39).

Passover occasions the final conflict between Jesus and the Jerusalem-based, Rome-allied elite which leads to Jesus' death (11:55-56; chs 18-19). The narrative foregrounds the festival, referring to Passover $(13: 1 ; 18: 28,39)$ and its preparation $(12: 12,20 ; 13: 29)$ and by counting down toward it: 'six days before Passover' (12:1), 'the next day' (12:12), 'the day of preparation' $(19: 14,31)$. The elite's condemnation of Jesus (18:31) and their exclusion of him from Imperial society through crucifixion $(19: 12,15-16)$ manifests their rejection of God's purposes and agent for which their judgment or condemnation is inevitable. Another festival, a Sabbath, is the occasion for Jesus' resurrection $(19: 31 ; 20: 1,19)$ and demonstration of God's life-giving power over opponents who cannot keep him dead. Jesus' resurrection evokes traditions concerning the world's destiny and cosmic order, whereby God's justice-bringing work condemns tyrants and sovereignly establishes God's world (Dn 12:1-3; 2 Macc 7).

The narrative thus constructs festivals as, among other things, significant occasions of conflict and condemnation involving Jesus and the Jerusalem-based, Rome-allied elite.

\section{Festivals}

\section{Intertextuality between Gospel narrative and Ephesus}

For Ephesian Jesus-believers who, along with some or many in synagogues, were participants in civic festivals, what happens in the cultural intertextuality between the Gospel's construction of festivals as (in part) occasions of conflict and condemnation and the various civic festivals that pervaded Ephesus?

10.The man called Jesus, 9:11; a prophet, 9:17; from God, 9:33; Son of Man, 9:35-38.
Firstly, the Gospel's presentation of festivals as occasions of conflict and condemnation destablilises and problematises festivals in Ephesus. By locating conflict between Jesus and the Jerusalem-based, Rome-allied elite in the context of festivals and by showing this conflict to be a matter of lifeand-death, John's narrative contests the civic presentation of festivals as a normative or 'innocent' part of daily Ephesian reality. Festivals, so pervasive in the city's temporal, spatial, cosmic, and social order, become, in the Gospel's narrative world, problematic times and spaces marked by conflict, especially with powerful elites who create and secure the city's social order and sacred identity (Rogers 1991). While festivals sanction Ephesian life under the blessing of Artemis and other deities and of Rome's divinely-sanctioned power, the Gospel's presentation counters such ordering. It shows festivals to be conflictual occasions marked by opposition to the divine purposes revealed by God's agent Jesus who condemns those who do not 'receive' him. Contrary to the celebratory, carnival-like, atmosphere shared by elites and non-elites, festivals (and the related temples and deities) become, through this intertextuality, oppositional times and places.

The intertextuality, for example, between the festival of Dedication (Hanukkah) and civic festivals in Ephesus exemplifies these dynamics (10:22-39). The Gospel narrative concerning Dedication presents intense conflict between Jesus and the Ioudaioi over Jesus' relationship with God (10:30-31) and his mission (10:36); it speaks of stoning (10:31), blasphemy (10:32-38) and arrest (10:39). Commonly, interpreters explore the intertext with Dedication in terms of the Jerusalem temple, whereby the narrative co-opts and contests the festival's central symbol of a dedicated altar to declare Jesus as God's 'sanctified one,' the new temple who reveals divine presence and purposes (10:36). But other intertexts dominate the Ephesian civic context. The temples and festivals of the Imperial cult celebrate an empire dedicated by Jupiter to be the agent of the gods. The temple and festivals of Artemis celebrate the city dedicated to her service and a goddess dedicated to the well-being of Ephesus. The Gospel narrative about Dedication or Hanukkah makes an exclusive and counter claim. Dedication celebrated not only the victory of faithful resistance to Antiochus IV Epiphanes' attempt to dismantle Jewish observance and identity and to install idolatrous practices (1 Macc 1$)$. It also celebrated the defeat of those who actively embraced Hellenistic culture and participated in Antiochus' program, including participants in cultic rituals (1 Macc 1:11-15, 52). The effect of evoking such traditions and symbols is to suggest that Jesus-believers participating in these civic festivals and rituals should not do so. With its proclamation of Jesus as God's sanctified one (10:36), John's narrative functions in this Ephesian context to disqualify understandings of Imperial or Artemis festivals or any other civic rituals as divinely 'dedicated' and worthy of participation.

Moreover, the interface between the Gospel narrative and civic Ephesian festivals reveals fundamental incompatibilities between Jesus' God-given mission and the civic status 
quo of Ephesus. The narrative probes beneath the claims associated with Artemis, Rome and various other gods of divine blessing, cosmic ordering, social bonding, and the celebration of central civic values and practices effected by civic festivals to highlight profound questions that are central to the Gospel's agenda. The conflicts that occur in the context of the Gospel's festivals involve recurring Christological affirmations that center on, or relate to, the mission of Jesus as God's agent: the revelation of the divine, ${ }^{11}$ mediating divine encounter, ${ }^{12}$ matters of cosmic order, sovereignty and destiny, life and death, ${ }^{13}$ accountability to the divine ${ }^{14}$ and a recognition of the locus of divine blessing and life-giving purposes. ${ }^{15}$ One likely implication of the Gospel's relentless insistence that Jesus alone provides the legitimate means of encountering the divine ${ }^{16}$ and of its dualistic, pervasive 'either/or' worldview is that there is no room for Jesusbelievers to assent to crucial claims of Ephesian civic festivals that the emperor and/or Artemis and/or Demeter and/or Dionysus are legitimate manifestations of divine presence or blessing, or that their festivals are places of legitimate divine encounter and sources of life.

The latter concern is important since civic festivals and temples had extensive economic reach (de Light and de Neeve 1988). In the Gospel's narrative, at Passover, Jesus attacks the temple ${ }^{17}$ as a 'market place' $(2: 16)$ or, as Van Tilborg

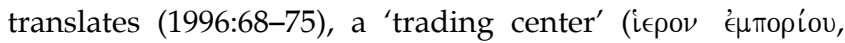
citing Zech 14:21). Such a description - along with Jesus

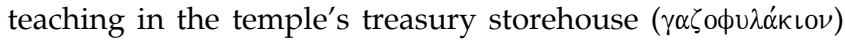
during Tabernacles (8:20) - establishes a strong resonance with the extensive commercial reach of temples and festivals in Ephesus such as those of the Sebastoi and Artemis (Van Tilborg 1996:71-74). ${ }^{18}$ Jesus' command to 'tear down this temple...' (2:19a) and the reference to Jesus as the $\nu \alpha o$ s in whom God is known $(2: 21 ; 14: 7,9,10)$ then builds on this resonance to disqualify temples and festivals as places and times of legitimate encounter with the divine for Jesusbelievers. The intertext of Zech 14:21 evoked by John 2:16 elicits an eschatological judgment scenario in which there will be no more 'traders in the house of the Lord of hosts on that day,' further suggesting (given the gospel's realised eschatology, 3:16-18 5:24) that they are condemned places from which Jesus-believers should keep their cultic, cultural, economic, and political distance. Underlining the assertion of God's supreme victorious purposes is, of course, the context of Passover itself, which celebrates God's victory over, and

11.John $5: 19-30 ; 7: 14-18 ; 8: 12-19 ; 9: 30-33 ; 10: 37-38 ; 12: 44-50 ; 18: 5-8,33-37$ 19:8-11, 17-30; ch. 20

12.John 2:19-21; 5:19-30; 6:41-58; 7:14-18; 9:10-40; 10:37-38; 12:44-50; 18:5-8, $33-37,19: 8-11,17-30 ;$; ch. 20

13.John 5:25-29; 6:35-40; 10:27-30; 12:47-49; chs 18-20.

14.John 5:22-29; 7:14-18; 12:31-36, 44-50.

15.John $5: 10-21 ; 6: 22-40 ; 9: 10-40 ; 12: 44-50 ;$ chs 18-20.

16. John $5: 23,36 ; 6: 27-29,44 ; 7: 17 ; 8: 19,31-32 ; 10: 25,38 ; 12: 44-50$ etcetera.

17.Van Tilborg (1996:68-75) notes that John's two terms for the temple voó $\varsigma$ and i foóv (Jn 2:14, 19, 20, 21) appear in Ephesian inscriptions for the temples of Artemis and the Sebastoi.

18.Dio Chrysostom, Discourse 31.54; Strabo, Geography 14.1.24; Aristides, Oration 42.522 . annihilation of, Egyptian power. As it went for a past empire, so it goes for the present empire whose celebrations and presence were deeply intertwined with local civic festivals (Carter 2008:58-64). Jesus insists that the only God (5:44), the only true God (17:3) whom he alone reveals (1:18), be honoured. The intertextuality between this temple conflict scene and the Ephesian context indicates that Jesus-believers should not participate in this extensive cultic-economic dimension of Ephesian societal life.

While some Jesus-believers in Ephesus seem to think that festival participation is harmless and meaningless, interaction with John's Gospel indicates an alternative perspective. The Gospel's presentation of festivals as occasions of conflict and condemnation interfaces with civic Ephesian festivals, deeming them not to be innocent or harmless events in which participation poses no problems; rather, they are deadly. Jesus attends festivals while pursuing his own identity and mission, yet he is, ultimately, rejected in being crucified at Passover. Festivals as times and spaces of conflict and condemnation under elite control present 'the world's' commitment to that which is contrary to God's purposes. Absence from them seems necessary for Jesus-believers.

The Gospel presentation of festivals is a further example of the Gospel's 'rhetoric of distance.' This rhetoric like the Gospel's dualisms, realised eschatology, Christological images or titles and notions of eternal life (Carter 2008) function to urge civically-involved believers to distant themselves from civic participation. ${ }^{19}$ By constructing festivals around conflict and condemnation and by evoking biblical narratives of liberation from Egyptian and Seleucid hegemony, the Gospel narrative (read in relation to Ephesus' festivals) underlines a profound incompatibility between Jesus-believers, accommodated synagogues and civic life. Social distance or retreat is the required response to the rhetoric of distance. Just what such 'social distance' might look like when festivals were so profoundly embedded in the city's structures and daily life, and whether some or many Jesus-believers in the city adopted the Gospel's perspective, are matters, regrettably, beyond our reach.

\section{References}

Barclay, J.M.G., 1996, Jews in the Mediterranean diaspora from Alexander to Trajan (323 BCE-117 CE), T \& T Clark, Edinburgh.

Barton, S., 1981, 'A Hellenistic cult group and the New Testament churches', Jahrbuch für Antike und Christentum 24, 7-41.

Barton, C., 2001, Roman honor: The fire in the bones, University of California Press, Berkeley.

Boatwright, M., 1991, 'Plancia Magna of Perge: Women's roles and status in Roman Asia Minor', in S. Pomeroy (ed.), Women's History and Ancient History, pp. 249-272, University of North Carolina, Chapel Hill.

Brown, R., 1979, The Community of the beloved disciple, Paulist, New York.

Broughton, T.R.S., 1938, 'Roman Asia Minor,' in T. Frank (ed.), An Economic Survey of Ancient Rome, vol. 4, pp. 449-916, Johns Hopkins Press, Baltimore.

Carter, W., 2004, 'Going all the way? Honoring the emperor and sacrificing wives and slaves in 1 Peter 2:13-3:6', in A.J. Levine (ed.), A Feminist companion to the Catholic Epistles and Hebrews, pp. 14-33, T \& T Clark, London.

19.I develop this rhetoric in Carter (2008), arguing that it embraces plot, genre, Christology, soteriology, eschatology, and ecclesiology, seeks to disrupt considerable societal accommodation, reveal the 'true' (evil) nature of the Imperially-controlled world and separate Jesus-believers from the synagogue's lifestyle. 
Carter, W., 2008, John and empire: Initial explorations, Continuum, New York.

Carter, W., 2009, 'Accommodating "Jezebel" and withdrawing John: Negotiating empire in Revelation then and now', Interpretation 63, 32-47.

Daise, M.A., 2007, Feasts in John: Jewish festivals and Jesus' 'hour' in the fourth Gospel, Wissenschaftliche Untersuchungen zum Neuen Testament 229, Mohr Siebeck, Tübingen

De Ligt, L. \& De Neeve, P.W., 1988, 'Ancient periodic markets, festivals, and fairs,' Athenaeum 66, 391- 416

Friesen, S., 1993, Twice Neokoros: Ephesus, Asia and the cult of the Flavian Imperial family, E.J. Brill, Leiden.

Friesen, S., 1995, 'The cult of the Roman emperors in Ephesos: Temple wardens, city titles, and the interpretation of the revelation of John', in H. Koester (ed.), Ephesos: Metropolis of Asia, pp. 229-250, Trinity Press International, Valley Forge.

Gruen, E., 2002, Diaspora: Jews amidst Greeks and Romans, Harvard University Press, Cambridge.

Haenchen, E., 1984, John, vol. 1, Fortress, Philadelphia.

Harland, P., 1996, 'Honours and worship: Emperors, Imperial cults and association at Ephesus (first to third centuries C.E.)', Studies in Religion/Sciences Religieuses 25, 319-334.

Harland, P., 2000, 'Honoring the emperor or assailing the beast: Participation in civic life among associations (Jewish, Christian and Other) in Asia Minor and the civic life among associations (Jewish, Christian and Other) in Asia Minor and the
apocalypse of John', Journal for the Study of the New Testament 77, 99-121.

Harland, P., 2003, Associations, synagogues, and congregations, Fortress, Minneapolis. doi:10.1177/0142064X0002207705

Joshel, S.R., 1992, Work, identity, and legal status at Rome: A study of the occupational inscriptions, University of Oklahoma Press, Norman \& London.

Kearsley, R.A., 1986, 'Asiarchs, Archiereis, and the Archiereiai of Asia', Greek, Roman and Byzantine Studies 27, 183-192.

Keener, C., 2003, The Gospel of John: A commentary, Hendrickson, Peabody.

Kerr, A.R., 2002, The Temple of Jesus' Body: The Temple Theme in the Gospel of John, Journal for the Study of the New Testament, suppl. 220, Sheffield Academic Press, Sheffield.
Kloppenborg, J. \& Wilson, S. (eds.), 1996, Voluntary Associations in the Graeco-Roman World, Routledge, London/New York.

Kraemer, R.S., 1992, Her Share of the Blessings: Women's Religions among Pagans, Jews, and Christians in the Greco-Roman World, Oxford University Press, New York.

Kraybill, J.N., 1996, Imperial cult and commerce in John's apocalypse, Journal for the study of the New Testament, suppl. 132, Sheffield Academic Press, Sheffield.

MacMullen, R., 1980, 'Woman in Public in the Roman Empire', Historia 29, 208-218.

Meijer, F. \& Nijf, O.V., 1992, Trade, transport, and society in the ancient world: A sourcebook, Routledge, London.

Millar, F., 1977, The Emperor in the Roman World, Duckworth, London.

Mitchell, S., 1990, 'Festivals, games, and civic life in Roman Asia Minor', Journal of Roman Studies 80, 183-193. doi:10.2307/300289

Oster, R., 1990, 'Ephesus as a religious center under the Principate, I. Paganism before Constantine', in H. Temporini (Hrsg.), Aufstieg und Niedergang der römischen Welt II.18.3, pp. 1662-1728, Walter de Gruyter, Berlin.

Pleket, H., 1965, 'An aspect of the emperor cult: Imperial mysteries', Harvard Theological Review 58, 331-347.

Price, S., 1984, Rituals and power: The Roman Imperial cult in Asia Minor, Cambridge University Press, Cambridge.

Rogers, G., 1991, The sacred identity of Ephesus, Routledge, London.

Trebilco, P., 1991, Jewish communities in Asia Minor, Society for New Testament Studies, Monograph Series 69, Cambridge University Press, Cambridge.

Van Tilborg, S., 1996, Reading John in Ephesus, E.J. Brill, Leiden.

Wankel, H., (Hrsg.) 1979-1984, Die Inschriften von Ephesos Vols 1A-8.2, Habelt, Bonn.

Wood, S.E., 1999, Imperial women: A study in public images, 40 B.C.-A.D. 68, E.J. Brill, Leiden.

Yee, G., 1989, Jewish feasts and the Gospel of John, Michael Glazier, Wilmington. 